To cite this article: Martha Martínez-Banfi, Jorge I. Vélez, M. Victoria Perea, Ricardo García, Pedro J. Puentes-Rozo, Moises Mebarak Chams \& Valentina Ladera (2018): Neuropsychological performance in patients with asymptomatic HIV-1 infection, AIDS Care, DOI: 10.1080/09540121.2018.1428728

\title{
Neuropsychological Performance in Patients with Asymptomatic HIV-1 Infection
}

\author{
Martha Martínez-Banfia ${ }^{a, *}$, , Jorge I. Vélez ${ }^{\mathrm{b}}$, M. Victoria Perea ${ }^{\mathrm{c}}$, Ricardo García $^{\mathrm{c}}$ \\ Pedro J. Puentes-Rozo ${ }^{\mathrm{a}, \mathrm{d}}$, Moises Mebarak Chams ${ }^{\mathrm{e}}$, Valentina Ladera ${ }^{\mathrm{c}}$
}

${ }^{a}$ Grupo de Neurociencias del Caribe, Universidad Simón Bolívar, Barranquilla, Colombia.

${ }^{\mathrm{b}}$ Departamento de Ingeniería Industrial, Universidad del Norte, Barranquilla, Colombia.

${ }^{\mathrm{c}}$ Facultad de Psicología, Universidad de Salamanca, España

${ }^{\mathrm{d}}$ Grupo de Neurociencias del Caribe, Universidad del Atlántico, Barranquilla, Colombia.

${ }^{\text {e }}$ Departamento de Psicología, Universidad del Norte, Barranquilla, Colombia

*ORCID www.orcid.org/0000-0003-2730-7590

${ }^{\#}$ Correspondence to be directed to:

Dr. Martha Martinez-Banfi

Grupo de Neurociencias del Caribe,

Laboratorio de Neurociencias Cognitivas,

Calle 54 \# 59 -189, Sede 1, Bloque C,

Universidad Simón Bolívar

Barranquilla, Colombia.

E-mail: mmartinez108@unisimonbolivar.edu.co

Phone +57 (5) $3444333 \times 228$ 


\begin{abstract}
Human immunodeficiency virus (HIV-1) infection and acquired immunodeficiency syndrome (AIDS) lead to neurocognitive disorders; however, there is still much knowledge to be gained regarding HIV-associated neurocognitive disorders. The purpose of this study was to assess the cognitive performance, instrumental activities of daily living, depression, and anxiety in patients with asymptomatic HIV-1 infections compared with seronegative participants without neurocognitive impairment. We studied a sample consisted of 60 patients with asymptomatic HIV-1 infections and 60 seronegative participants without neurocognitive impairment from the city of Barranquilla, Colombia, with a mean age of 36.07 years. A protocol of neuropsychological and psychopathological tests was applied to the participants. The group of patients with asymptomatic HIV infections significantly underperformed on tasks that assessed global cognitive screening, attention span, learning, phonemic verbal fluency, auditory-verbal comprehension, information processing speed, cognitive flexibility, and motor skills compared to the group of seronegative participants. No significant differences were found in memory, visual confrontation naming, vocabulary, inhibition, and instrumental activities of daily living. Additionally, the patients with asymptomatic HIV-1 infection had a higher anxiety index than the seronegative participants, but no significant difference was found in depression. A correlation was found between depression and anxiety. In conclusion, the patients with asymptomatic HIV-1 infection had lower cognitive performances than the seronegative participants in the cognitive functions mentioned above and more anxiety but still performed the instrumental activities of daily living.
\end{abstract}

Keywords: Human Immunodeficiency Virus; Asymptomatic; HIV-associated dementia; Neurocognitive Impairment in HIV-1; HIV-associated Neurocognitive Disorders. 


\section{Introduction}

Human immunodeficiency virus (HIV) is a neurotropic and immunotropic virus that compromises the immune system by infecting CD4 lymphocytes (Croucher and Winston, 2013), and can affect any cognitive function in individuals with HIV infection, although some are more commonly affected than others (Heaton et al 2010). According to figures from ONUSIDA (2015a), 36.9 million people were living with HIV worldwide at the end of 2014, of which 120,000 resided in Colombia (ONUSIDAb). HIV-associated neurocognitive disorders (HAND) are one clinical manifestation of the virus (Antinori et al., 2007). These disorders are characterized by cognitive and behavioral disorders in which any cognitive function can be affected (Bragança and Palha, 2011)

HIV-associated neurocognitive disorders are classified as "asymptomatic neurocognitive impairment (ANI)", "mild neurocognitive disorder (MND)", and "HIV-associated dementia (HAD)" (Antinori et al., 2007; Guevara-Silva et al., 2014; Kalinowska Trześniowska-Drukała \& Samochowiec, 2013). ANI is characterized by mild neurocognitive deficits (MND) without reported functional impairment (Antinori et al., 2007); MND is characterized by mild or moderate impairment of at least two neurocognitive areas with effects on the activities of daily living of the patient (Antinori et al., 2007), and HAD consists of moderate to severe impairment of at least two neurocognitive areas and severe functional impairment (Antinori et al., 2007). These disorders become more severe in the more advanced stages of the disease (Kalinowska et al., 2013 and Vally, 2011).

HIV-infected people may present with neurocognitive disorders at any stage of the infection (Bragança and Palha, 2011; Guevara-Silva et al., 2014), and HIV-infection is a risk factor for neurocognitive impairment (Abusamra et al., 2014; Custodio, Escobar, and Altamirano, 2006; Galindo-Sainz, Rodríguez-Almanza, Sandoval-Ramírez, and Tejada-García 2010; Habib et al., 2013; Heaton et al., 2017; Rackstraw, 2011). Currently, one concern is the detection of early cognitive impairment (Ian et al., 2015) during the asymptomatic stage of the infection, which will 
help determine the treatment protocol. Despite of this situation, very few studies in Colombia have investigated neurocognitive disorders in patients with asymptomatic HIV-infection (Arciniegas et al., 2013). This topic should be considered relevant due to its implications not only for research but also for neuropsychological prevention and intervention, which should have more clearly defined roles in the comprehensive care of these patients. Although the HIV/AIDS guidelines in Colombia mention neuropsychological assessment (Ministerio de Salud y Protección Social y Fondo de Población de las Naciones Unidas, 2014), the procedure and protocols for diagnostic tests are not clear, and neuropsychological rehabilitation is not even contemplated (Pino-Melgarejo and OmarMartínez, 2014) despite its potential effects (Bragança \& Palha, 2011; Weber, Blackstone \& Woods, 2013). The aim of this investigation is to study the cognitive performance, instrumental activities of daily living, depression, and anxiety in patients with asymptomatic HIV-infection. 


\section{Subjects and Methods}

\section{Subjects}

The total sample consisted of 60 patients with asymptomatic HIV-infections and 60 seronegative participants without neurocognitive impairment (control group). The definition of asymptomatic HIV is released by the Centers for Disease Control and Prevention, USA (Castro et al., 1993), which refers to disease status and not to neurocognitive status. The inclusion criteria for the patients were as follows: (i) infected with HIV in the asymptomatic stage; (ii) age between 18 and 58 years; (iii) at least two years of education; (iv) time since HIV diagnosis of up to 9 years; and (v) no history of alcohol and/or drug use or neurological, neuropsychological, and/or psychopathological disorders prior to HIV -infection in the patient's medical record. The control group met the same inclusion criteria as the asymptomatic group with HIV infection but was not infected with HIV. Table 1 describes the sociodemographic characteristics of the participants.

\section{Instruments}

The cognitive performance of the participants was measured with a neuropsychological assessment battery that included cognitive screening, attention span, verbal learning and memory, visual memory, language, information processing speed, visuoconstructive skills, executive function, depression, and anxiety tests (See Table 2 and Supplementary Material). Anxiety state, depression, and instrumental activities of daily living were also evaluated (see Table 2 and Supplementary Material). These tests were selected based on the systematic review of different proposals for neuropsychological assessment batteries for the HIV-infected population (Ardila-Ardila et al., 2003; Ayuso-Mateos 1997; Burgess et al., 1994; Butters et al., 1990; Maj, Starace, and Sartorius, 1991; Selnes and Miller, 1994).

\section{Procedure}

Informed written consent was obtained from all participants. This study was carried out in accordance with local review board approval. The neuropsychological tests were administered in 
two sessions. After all data were collected, the neuropsychological and psychopathological tests and the activities of daily living were graded.

\section{Statistical analysis}

Measures of central tendency and dispersion were estimated for the continuous variables, and frequencies and proportions were calculated for the categorical variables. The normality of the continuous variables was assessed using the Shapiro-Wilks test. The categorical variables were analyzed using the $\chi^{2}$ test.

Student's $t$-test and the Mann-Whitney $U$ test were performed to compare the means of the hypothesis tests. Cohen's standardized effect size $(d)$ was calculated. To correct for potential confounding effects of the demographic variables, such as age, gender, and years of education, on the cognitive variables, analysis of covariance (ANCOVA) was used to compare the performances of the HIV-infected and seronegative individuals. In this case, the partial $\eta^{2}$ parameter was used to estimate the effect size. To explore potential relationships between neuropsychological tasks, we used Pearson's linear correlation coefficient. Because many statistical hypotheses were tested when comparing the neuropsychological performance of HIV-infected individuals with that of seronegative individuals, we used the False Discovery Rate (FDR) procedure (Benjamini \& Hochberg, 1995) and a method based on extreme-value theory (Vélez, Correa, \& Arcos-Burgos, 2014) to control for multiple comparisons. The FDR procedure was chosen as it controls the proportion of wrongly rejected null hypotheses amongst those that are rejected, not amongst all hypotheses being tested (Groppe, 2016; Storey \& Tibshirani, 2003) and hence more powerful than Bonferroni's correction (Groppe, Urbach, \& Kutas, 2011; Storey \& Tibshirani, 2003; Vélez et al., 2014). Unless otherwise stated, all statistical analyses were performed in R version 3.3.3 (R Core Team, 2016). 


\section{Results}

The mean time since diagnosis in the HIV- infection patients was $3.32 \pm 2.5$ years, and $81.67 \%$ of the patients were on antiretroviral therapy (ART). The mean number of CD4 cells was $310.2 \pm 87.6$ cells $/ \mu \mathrm{L}$. The median viral load was 11,260 copies $/ \mathrm{mL}$, and the average logarithm of the viral load was 9.136 \pm 3 . Significant differences were found $(P<0.05$, Table 1$)$ in hand preference, age, and years of education when comparing the compositions of the group of patients with asymptomatic HIV- infections and the seronegative controls.

We observed that patients with asymptomatic HIV underperformed compared to the individuals in the control group in the global cognitive screening, attention span, learning, language (i.e., vocabulary), phonemic verbal fluency and auditory-verbal comprehension, information processing speed, cognitive flexibility, motor skills as part of the executive function, and anxiety tests $(P<0.05$, Table 3$)$. However, no differences were found in verbal and visual memory, naming, inhibition, and ability to perform instrumental activities of daily living, which were also conserved in patients with asymptomatic HIV $(P>0.05$, Table 3$)$. Additionally, patients with asymptomatic HIV had higher anxiety indices than the seronegative individuals, but no significant differences were found in the depression indices. Overall, laterality (i.e., being right-handed) improves the performance in the WAIS vocabulary subtest, and the total score of the Controlled Word Association Test, whilst years of education and age have a positive effect (i.e., there is an improvement) on 58\% (25/43) of all cognitive tests, and on 9\% (4/43) of memory and information processing speed neuropsychological tests (i.e., digit symbol-coding, test 3 and sum of tests 1 to 5 of the Rey Auditory-Verbal Learning Test, and the memory subtests of the Rey Complex Figure Test), respectively (Supplementary Table 1).

Figure 1a shows the mean corrected differences of the neuropsychological tests $(\beta$ coefficient, Table 3 ) as a function of the $P$ value. In this case, values of $\beta>0$ imply that the individuals with asymptomatic HIV-1 infections have higher mean scores than the seronegative 
individuals, whereas values of $\beta<0$ indicate that the seronegative individuals have scored lower than the patients with asymptomatic HIV-infections (Figure 1a). Particular attention is drawn to the following tests because the individuals with asymptomatic HIV- infections have lower performance scores: digit symbol-coding $\left(\beta=-7.566, P=2.53 \times 10^{-3}\right.$, Table 3$)$; Stroop interference score $(\beta=-7.484$, $P=0.0276$, Table 3); total score of the Controlled Word Association Test $\left(\beta=-5.992, P=5.54 \times 10^{-3}\right.$, Table 3); Stroop color score ( $\beta=-5.348, P=0.0251$, Table 3); Trail Making Test Part $\mathrm{B}$, number of errors $(\beta=2.307, P=0.0679$, Table 3); Boston Naming Test, phonemic clues $(\beta=2.410, P=0.0139$, Table 3$)^{1}$; State Anxiety Inventory $(\beta=4.687, P=0.0158$, Table 3); and Trait Anxiety Inventory ( $\beta=6.633, P=0.0018$, Table 3 ). Figure $1 \mathrm{~b}$ shows the results for each of the neuropsychological variables that are relevant for the differentiation of individuals with asymptomatic HIV- infections from seronegative individuals. For each test, relevance was determined using the ratio between the value of $\beta$ and its standard error. These results suggest that tasks 36, 33, 37, and 35 (see Table 3 ) are the most relevant for this differentiation. This result is consistent with previous research of HIV associated neurocognitive disorders, which have reported the impairment of cognitive flexibility (Venier, et al., 2012) and have established that motor skills are the first skills to be affected (GESIDA and SPNS, 2014; Vally, 2011).

Across all neuropsychological tasks, the average effect size $d$ was $0.565 \pm 0.304$ (range 0 1.331; Table 3) and increased to $0.7475 \pm 0.209$ (range 0.508-1.331; Table 3) when only significant neuropsychological tasks that differed between the HIV asymptomatic and seronegative individuals were considered (Table 3 and Figure 1). These results indicate medium-to-large effect sizes of these tasks when contrasting the performances of the HIV asymptomatic and seronegative individuals. We found that the Beck Depression Inventory, Anxiety Inventory (State) and Anxiety Inventory (Trait) are positively correlated with each other regardless of HIV status (Figure 2). In particular, the correlation Anxiety Inventory (State) and Anxiety Inventory (Trait) was $0.654\left(P_{\mathrm{FDR}}<0.0001\right)$ in

\footnotetext{
${ }^{1}$ Although it is promising that the phonemic clues subtest in the Boston Naming Test is the only subtest statistically significant after correction for multiple testing, this result is not enough to conclude that naming capacity is different between individuals with HIV infection and those with asymptomatic HIV.
} 
patients with HIV- infection and 0.844 in controls $\left(P_{\mathrm{FDR}}<0.0001\right)$, whilst the correlation between Anxiety Inventory (State) and BDI was $0.629\left(P_{\mathrm{FDR}}<0.0001\right)$ in patients with HIV- infection and 0.497 in controls $\left(P_{\mathrm{FDR}}<0.0001\right)$, and between Anxiety Inventory (Trait) and BDI was 0.702 $\left(P_{\mathrm{FDR}}<0.0001\right)$ in patients with HIV- infection and 0.638 in controls $\left(P_{\mathrm{FDR}}<0.0001\right)$. In all cases, the resulting correlations differed between cases and controls $\left(P_{\mathrm{FDR}}<0.05\right)$. There is a correlation between anxiety and depression. However, this correlation is stronger in the group of cases which may suggest that being infected with the HIV makes them more vulnerable to comorbid psychiatric disorders (Beckford et al., 2017). 


\section{Discussion}

The aim of this study was to evaluate the cognitive performance, instrumental activities of daily living, depression, and anxiety in patients with asymptomatic HIV-infections. The results show the existence of cognitive impairment in subjects with asymptomatic HIV-infections. This finding agrees with the results of other studies (Amador \& Mayor, 2005; Guevara-Silva et al., 2014; Salawu et al., 2008), which stated that cognitive dysfunction in patients with HIV might be present from the early stages of infection and might occur in neurologically asymptomatic patients.

The findings of the present study are in line with other studies that also reported poorer performances in patients with asymptomatic HIV -infections in the following variables: attention span (Amador and Mayor 2005; Arciniegas, Malagón, Halliday, and Tovar-Cuevas, 2013; information processing speed (Vally, 2011; Vásquez \& Rodríguez, 2001; Woods et al., 2009); visuoconstructive skills (Hesse et al., 2003; Guevara-Silva, 2013 and Villaseñor \& Rizo, 2003); learning (Cysique, Maruff, Darby, and Brew, 2006; Paul, Cohen, Navia \& Tashima, 2002), phonemic verbal fluency and auditory-verbal comprehension (Pino-Melgarejo, 2015; GESIDA [Spanish AIDS study group] and SPNS [Spanish Secretariat for the National Plan on AIDS], 2014); and executive functions, especially cognitive flexibility (Venier et al., 2012) and motor skills (Amador et al., 2006; Vally, 2011). In addition to the significant differences between groups in these cognitive performances, medium-to-large effect sizes were also observed, which demonstrated the sensitivity of the neuropsychological tests used to differentiate patients with asymptomatic HIVinfections from the seronegative controls and associated poor performances with HIV- infection.

It calls our attention that, although some studies have found memory impairment (Failde et al., 2009; Heaton et al., 2010; Vally, 2011) as well as alterations in inhibitory control (Arciniegas et $a l .$, 2013), these findings do not agree with those of the present study. This discrepancy could be due to other factors associated with HIV or the methodology used herein. Regarding the factors associated with HIV (time since infection, viral load, CD4 cell count, and ART), the likelihood of 
cognitive dysfunction is hypothesized to increase as HIV-infection progresses. Although neurological complications seem to be closely related to the time elapsed since the infection was acquired (Guevara-Silva, 2013; Woods et al., 2009), this relationship is not clear-cut (Towgood et al., 2012; Woods et al., 2009). Another aspect that perhaps could explain this difference is the evaluation instrument used because HIV-infected individuals who present asymptomatic or mild neurocognitive disorders may have subtle changes in memory that remain undetected due to a lack of a well-defined clinical protocol (Manzanera, 2014; Parry, Zetler, Kentridge, Petrak and Barber, 2017). However, Vergara et al. (2010) reported that memory was generally intact and therefore preserved in the early stages of HIV-associated minor cognitive motor disorder. Regarding naming, there is no specific report in the scientific literature about this function in patients with HIV, probably because this issue has not been sufficiently studied or the condition is uncommon.

We found that patients with asymptomatic HIV- infections presented higher anxiety rates than seronegative individuals, which agreed with the findings of other studies (Martin et al., 2002; Vera-Villaroel, Pérez, Moreno \& Allen, 2004). However, evidence supporting the existence of this highly prevalent disorder in individuals with HIV (Elliot, 1998) is not consistent with other studies (Perdices et al. 1992; McAllister et al. 1992; Mehta et al. 1996; Pumpradit et al. 2010) that do not report anxiety. We found no significant differences in depression measures between the patients with asymptomatic HIV -infections and the seronegative controls which coincides with the findings of (Maj, Starace, and Sartorius 1990; Martin et al., 2002) who have found depression in some symptomatic HIV patients, unlike Custodio et al., (2006) who did not find depression. The presence or absence of psychiatric disorders may be determined by characteristics of the virus and / or other psychosocial factors (Hill y Lee, 2013; Sánchez-Fernández \& Tomateo-Torvisco, 2014). In addition, a positive relationship between anxiety and depression was found, which was much stronger in the cases. This agrees with (Hill and Lee, 2013) who report a link between HIVinfection and psychiatric disorders. These findings may suggest that HIV-infection is a risk factor 
for the development of psychiatric disorders. As well as, in addition to infection, they may have comorbid psychiatric disorders that are neither diagnosed nor treated (Beckford et al., 2017); although other psychosocial factors associated with anxiety and depression have also been reported (Laverick et al., 2017) which should be taken into account in future research.

The statistically significant correlation between anxiety and depression in $\mathrm{HIV}^{+}$individuals (Figure 2) may potentially suggest that cognitive impairment could be associated with the presence of anxiety and depression disorders (Laverick et al., 2010). A recent systematic review urges for depression assessment in those with HIV infection as the appearance of depression is prior to HIV diagnosis (Sherr et al 2011). A similar study in Alzheimer's disease points out that depression and anxiety can trigger other psychiatric disorders (Jessen et al., 2014). Performance in daily living activities was preserved in assessed individuals, which agreed with Martin et al. (2002). The neurocognitive disorders already present in these subjects are most likely not severe enough to affect their functioning.

To the best of our knowledge, this study is the first in Colombia to assess the neuropsychological performances of individuals with asymptomatic HIV- infections which is a starting point for early diagnosis and decision-making regarding HAND treatment in our population. Mild cognitive impairment should be studied in its asymptomatic phase to detect individuals at risk of developing dementia and to perform the corresponding intervention (AcostaLópez, et al., 2015). Additionally, the resulting observed power calculated based on these effect sizes and assuming $60 \mathrm{HIV}-1$ asymptomatic individuals, an equal number of seronegative controls, and a significance level of 5\% (see Supplementary Material in Velez et al., 2016 for more details) using the pwr package (Champely, 2017) in R, ranged from $78.9 \%$ (task 3 ) to $>99.9 \%$ (tasks 38 and 39), with an average of $94.47 \%$.

The limitations of this study include not controlling for factors associated with HIV, such as the viral load and antiretroviral therapy, and how we were able to control for substance abuse, 
confounding medical conditions and psychiatric diagnoses. Clinical information from individuals that could potentially participate in this study was initially retrieved from medical records, which were carefully reviewed with the chief nurse of the Programa de Atención Integral of the two Health Institutions where the patients were recruited (see Acknowledgements section); this program is monitored by the Ministerio de Salud y Protección Social de Colombia. In addition to reviewing these clinical records, potential candidates were further interviewed; this interview included clinical questions such as age, years of education, time elapsed since diagnosis, sexual orientation, neurological and neuropsychiatric disorders, and substance abuse.

In conclusion, HIV may cause neurocognitive deficits that could potentially affect functioning at personal, family, social and work-related environments, and limit their quality of life, treatment adherence, and prevention of risk behaviours in the understudied region/population of Barranquilla, Colombia.-Our findings are a warning regarding the early onset and possible progression of cognitive impairment associated with HIV infection that require a precise and early diagnosis, which will contribute to the pharmacological and cognitive rehabilitation treatment. Future research studies should assess neurological and psychiatric information in individuals with HIV using standardized instruments and/or the protocol used in this study, and further replicate our findings in other regions of Colombia and/or other Latino and Non-Latino populations. Furthermore, longitudinal studies measuring cognitive performance and neurodegenerative processes in individuals with HIV are needed. These studies should include HIV-associated risk factors such as elapsed time since the infection, infection stage, viral load, CD4 count and antiretroviral treatment, in addition to neurological, psychiatric, psychosocial, ethnic and genetic data and its association with HAND (Marquine et al., 2017). In a subsequent stage of our research program, we plan to perform genetic studies using high-throughput sequencing technologies to better understand the contribution of virus-specific genetic variations and human-specific genetic variants to the differences in neurocognitive impairment our cohort of patients with HIV. 


\section{Acknowledgments}

We express our highest appreciation to all patients and their families who participated in this study.

We also thank IPS Medicina Integral S. A. and Quimiosalud of the city of Barranquilla, Colombia.

\section{Conflict of interest}

None of the authors of this paper had a financial or personal relationship with other people or organizations that could inappropriately influence or bias the content of the paper. 
Tables

Table 1. Sociodemographic characteristics of the participants.

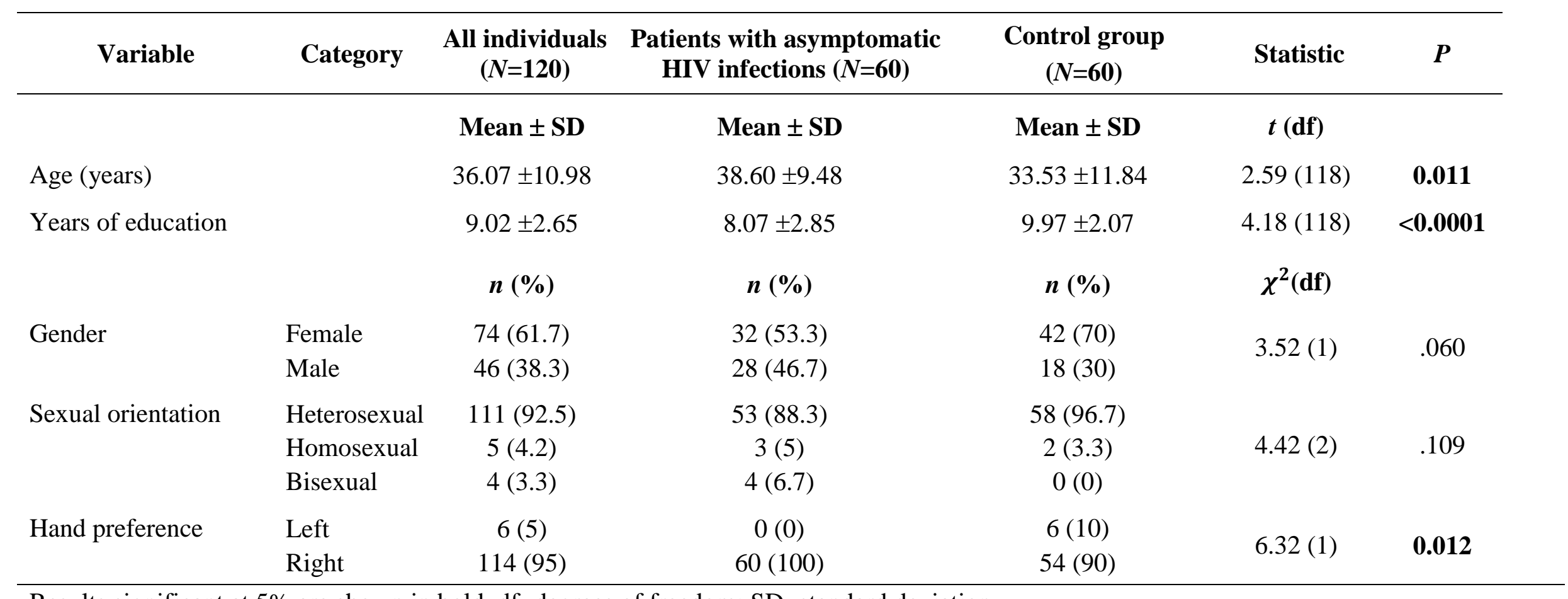

Results significant at 5\% are shown in bold. $\mathrm{df}=$ degrees of freedom; $\mathrm{SD}=$ standard deviation. 
Table 2. Variables (cognitive functions) and instruments used in the neuropsychological assessment battery. The Supplementary Material provides a detailed description of each of the tests used in the neuropsychological assessment battery.

\begin{tabular}{l|l}
\hline Cognitive function & Test \\
\hline Cognitive screening & $\begin{array}{l}\text { Mini-Mental State Examination (Folstein, } \\
\text { Folstein and McHung, 1975). }\end{array}$ \\
\hline Attention span & $\begin{array}{l}\text { Wechsler Memory Scale Digit Span Subtest } \\
\text { (Wechsler, 1972, 2004). }\end{array}$ \\
\hline Verbal learning and memory & $\begin{array}{l}\text { Rey Auditory Verbal Learning Test (Rey, } \\
\text { 1964; Schmidt, 1996) }\end{array}$ \\
\hline Visual memory & Rey Complex Figure Test (Rey, 2003) \\
\hline Language & $\begin{array}{l}\text { Boston Naming Test (Kaplan, Goddglass and } \\
\text { Weintraub, 1983) }\end{array}$ \\
\hline \multicolumn{1}{|l}{ Phoming } & $\begin{array}{l}\text { Controlled Word Association Test. (Spreen and } \\
\text { Strauss, 1998) }\end{array}$ \\
\hline Vocabulary & $\begin{array}{l}\text { Wechsler Intelligence Scale Vocabulary } \\
\text { Subtest (Weschler, 1997, 2001) }\end{array}$ \\
\hline Auditory-verbal comprehension & $\begin{array}{l}\text { Language Comprehension Subtest of the Brief } \\
\text { Neuropsychological Assessment in Spanish } \\
\text { (Otrosky-Solis, Ardila and Rosselli, 1999) }\end{array}$ \\
\hline Information processing speed & $\begin{array}{l}\text { Digit Symbol-Coding Subtest of the Wechsler } \\
\text { Intelligence Scale (WAIS-III) }\end{array}$ \\
\hline Visuoconstructive skills & Rey Complex Figure Test (Rey, 2003) \\
\hline Executive functions & \\
\hline Inhibition & STROOP Color-Word Test by Golden (2005) \\
\hline Cognitive flexibility & $\begin{array}{l}\text { Trail Making Test (TMT), Part B (Lezak, } \\
\text { 1983) }\end{array}$ \\
\hline Motor programming & $\begin{array}{l}\text { Motor Skills Subtest of the Brief } \\
\text { Neuropsychological Assessment in Spanish } \\
\text { (NEUROPSI) }\end{array}$ \\
\hline Depression & $\begin{array}{l}\text { Lawton and Brody Scale (Lawton and Brody, } \\
1969)\end{array}$ \\
\hline Bnxiety & $\begin{array}{l}\text { Trait-State Anxiety Inventory (STAI) } \\
\text { (Spielberger and Diaz, 1975) }\end{array}$ \\
\hline
\end{tabular}


Table 3. Performance on neuropsychological tests of the individuals with asymptomatic HIV -infections and the controls.

\begin{tabular}{|c|c|c|c|c|c|c|c|}
\hline \multirow{2}{*}{ Test } & \multirow{2}{*}{ Description } & \multicolumn{2}{|c|}{ Group } & \multirow{2}{*}{$d$} & \multirow{2}{*}{$\beta(\mathbf{S E})$} & \multirow{2}{*}{$\boldsymbol{P}$} & \\
\hline & & HIV & Control & & & & \\
\hline \multirow[t]{2}{*}{1} & Minimental & $27.55(1.9)$ & $29.05(1.11)$ & 0.964 & $-0.88(0.27)$ & 0.002 & $*$ \\
\hline & WMS-III & & & & & & \\
\hline 2 & Digit span & $9.48(2.44)$ & $11.38(3.18)$ & 0.671 & $-1.78(0.56)$ & 0.002 & $*$ \\
\hline 3 & Digit span forward & $6.38(1.54)$ & $7.32(2.09)$ & 0.509 & $-0.83(0.36)$ & 0.024 & \\
\hline \multirow[t]{2}{*}{4} & Digits span backward & $3.42(1.73)$ & $4.22(1.84)$ & 0.448 & $-0.66(0.36)$ & 0.066 & \\
\hline & Wechsler Intelligence Scale & & & & & & \\
\hline 5 & Vocabulary & $21.18(12.67)$ & $28.17(9.88)$ & 0.614 & $-5.01(2.12)$ & 0.020 & \\
\hline \multirow[t]{2}{*}{6} & Digit symbol-coding & $38.65(14.45)$ & $52.93(16.49)$ & 0.921 & $-7.57(2.54)$ & 0.003 & $*$ \\
\hline & Rey Auditory-Verbal Learning Test & & & & & & \\
\hline 7 & Test 1 & $4.87(1.73)$ & $5.47(1.68)$ & 0.351 & $-0.38(0.33)$ & 0.256 & \\
\hline 8 & Test 3 & $6.67(2.06)$ & $7.72(2.12)$ & 0.502 & $-0.43(0.39)$ & 0.278 & \\
\hline 9 & Test 3 & $7.5(2.8)$ & $9.37(2.55)$ & 0.698 & $-1.36(0.52)$ & 0.010 & $*$ \\
\hline 10 & Test 4 & $9.28(2.78)$ & $10.4(2.2)$ & 0.445 & $-0.59(0.47)$ & 0.213 & \\
\hline 11 & Test 5 & $9.8(2.87)$ & $11.42(2.08)$ & 0.645 & $-1.06(0.47)$ & 0.027 & \\
\hline 12 & Sum of tests 1 to 5 & $38.25(10.06)$ & $44.48(8.6)$ & 0.666 & $-3.6(1.71)$ & 0.038 & \\
\hline \multirow[t]{2}{*}{13} & Test 7 & $8.38(3.01)$ & $9.92(2.49)$ & 0.554 & $-0.53(0.49)$ & 0.286 & \\
\hline & Rey Complex Figure Test & & & & & & \\
\hline 14 & Copy & $31.73(5.91)$ & $34.78(3.19)$ & 0.642 & $-1.85(0.91)$ & 0.045 & \\
\hline 15 & Type of copy & $2.18(1.5)$ & $2(1.43)$ & 0.125 & $0.29(0.29)$ & 0.320 & \\
\hline 16 & Copy time & $4.48(1.78)$ & $4.37(1.65)$ & 0.068 & $-0.45(0.32)$ & 0.161 & \\
\hline 17 & Recall copy & $2.84(1.54)$ & $2.92(1.49)$ & 0.047 & $-0.26(0.3)$ & 0.397 & \\
\hline 18 & Memory & $16.55(8.25)$ & $20.83(8)$ & 0.527 & $-1.41(1.49)$ & 0.348 & \\
\hline \multirow[t]{2}{*}{19} & Recall time & $3.28(2.18)$ & $2.82(1.36)$ & 0.257 & $0.45(0.36)$ & 0.217 & \\
\hline & Boston Naming Test & & & & & & \\
\hline 20 & Total score & $47.83(7.54)$ & $50.07(5.87)$ & 0.331 & $-0.38(1.29)$ & 0.767 & \\
\hline 21 & Semantic clues & $8.73(5.85)$ & $5.88(3.66)$ & 0.584 & $1.58(0.94)$ & 0.095 & \\
\hline 22 & Correct responses to semantic clues & $3.1(2.54)$ & $3.33(2.52)$ & 0.092 & $-0.82(0.49)$ & 0.097 & \\
\hline 23 & Phonemic clues & $5.63(6.1)$ & $2.53(3.16)$ & 0.638 & $2.41(0.97)$ & 0.014 & \\
\hline
\end{tabular}




\begin{tabular}{|c|c|c|c|c|c|c|}
\hline 24 & Correct responses to phonemic clues & $0.42(0.93)$ & $0.33(1.17)$ & 0.079 & $-0.03(0.21)$ & 0.880 \\
\hline & \multicolumn{6}{|l|}{ Stroop } \\
\hline 25 & Interference & $-3.52(8.82)$ & $-5.85(8.92)$ & 0.264 & $2.06(1.77)$ & 0.246 \\
\hline 26 & Word & $85.27(19.22)$ & $97.15(15.76)$ & 0.676 & $-7.48(3.36)$ & 0.028 \\
\hline 27 & Color & $61(12.4)$ & $69.28(12.08)$ & 0.677 & $-5.35(2.36)$ & 0.025 \\
\hline \multirow[t]{2}{*}{28} & Word-color & $31.8(8.72)$ & $34.07(8.46)$ & 0.264 & $-0.98(1.69)$ & 0.563 \\
\hline & \multicolumn{6}{|l|}{ Controlled Word Association Test } \\
\hline 29 & Total score & $33.73(11.78)$ & $42.37(11.46)$ & 0.743 & $-5.99(2.12)$ & 0.006 \\
\hline 30 & Words with $\mathrm{P}$ & $13.1(4.79)$ & $15.7(4.72)$ & 0.547 & $-1.81(0.91)$ & 0.049 \\
\hline 31 & Words with $\mathrm{T}$ & $10.77(4.5)$ & $13.17(3.98)$ & 0.565 & $-1.36(0.77)$ & 0.082 \\
\hline 32 & Words with M & $10.13(4.28)$ & $13.28(3.92)$ & 0.768 & $-2.09(0.75)$ & 0.006 \\
\hline & \multicolumn{6}{|l|}{ Trail Making Test } \\
\hline 33 & Part B errors & $6.35(4.95)$ & $3.33(3.3)$ & 0.718 & $2.31(0.84)$ & 0.007 \\
\hline 34 & Part B time & $22.77(13.65)$ & $23.3(16.01)$ & 0.035 & $0.18(5.06)$ & 0.972 \\
\hline & \multicolumn{6}{|l|}{ NEUROPSI } \\
\hline 35 & Motor skills 1 & $2.5(1.23)$ & $3.67(0.6)$ & 1.207 & $-0.97(0.19)$ & $1.21 \times 10^{-6}$ \\
\hline 36 & Motor skills 2 & $1.4(0.76)$ & $1.82(0.47)$ & 0.658 & $-0.31(0.13)$ & 0.015 \\
\hline 37 & Motor skills 3 & $1.37(0.74)$ & $1.8(0.4)$ & 0.730 & $-0.42(0.12)$ & 0.001 \\
\hline 38 & Motor skills total score & $5.25(1.85)$ & $7.27(1.09)$ & 1.331 & $-1.71(0.3)$ & $7.87 \times 10^{-5}$ \\
\hline 39 & Auditory-verbal comprehension & $5.12(1.04)$ & $5.92(0.33)$ & 1.033 & $-0.65(0.15)$ & $3.95 \times 10^{-5}$ \\
\hline 40 & Lawton and Brody scale & $7.98(0.13)$ & $7.98(0.13)$ & 0.000 & $0.01(0.03)$ & 0.717 \\
\hline 41 & Beck Depression Inventory & $9.02(9.28)$ & $5.92(5.54)$ & 0.406 & $2.62(1.55)$ & 0.093 \\
\hline & \multicolumn{6}{|l|}{ Anxiety Inventory } \\
\hline 42 & State & $36.6(11.17)$ & $31.75(7.29)$ & 0.514 & $4.69(1.91)$ & 0.016 \\
\hline 43 & Trait & $41.77(11.66)$ & $35.38(8.65)$ & 0.622 & $6.63(2.08)$ & 0.002 \\
\hline
\end{tabular}

Significant differences at the $5 \%$ level are shown in bold, and differences significant after correction for multiple testing using the false discovery rate $(\mathrm{FDR})$ are marked with *. $\beta$ : regression coefficient; $d$ : Cohen's effect size; $P$ : $P$-value; SE: standard error. 


\section{Figures}

Figure 1. (a) $-\log _{10}(P)$ as a function of $\beta$, representing the corrected differences in the neuropsychological test; (b) importance of neuropsychological tests for the differentiation of the HIV asymptomatic individuals from the controls. The neuropsychological tests are numbered as described in Table 3.

Figure 2. Scatterplot matrix of anxiety and depression neuropsychological tests in patients with asymptomatic HIV- infection (pink dots/lines) and controls (blue dots/lines). Estimated pairwise Pearson's linear correlation between tests are shown in the upper-left and bottom-right corners. Statistically significant correlations after correction for multiple testing using FDR are marked with *. AI: Anxiety Inventory; BDI: Beck Depression Inventory.

Figure 1
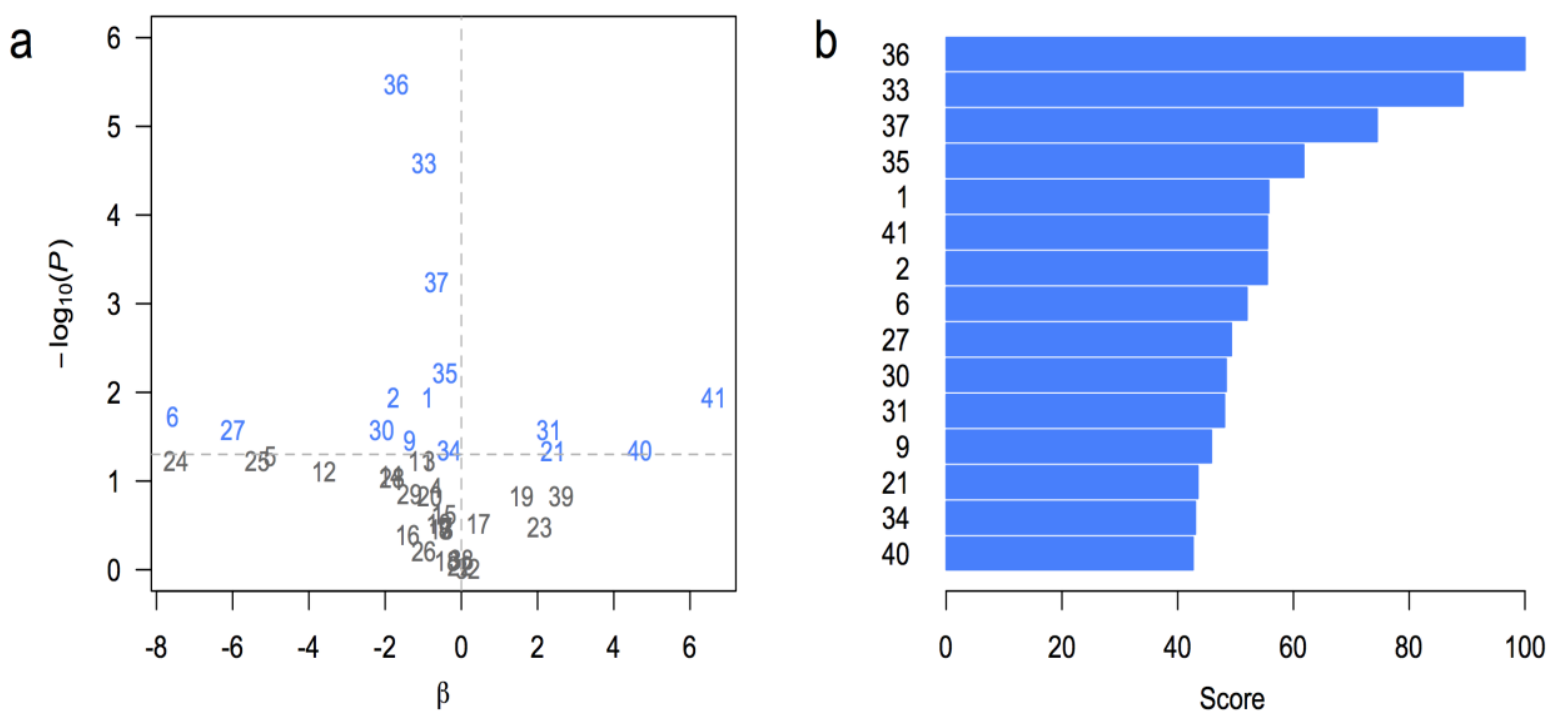
Figure 2
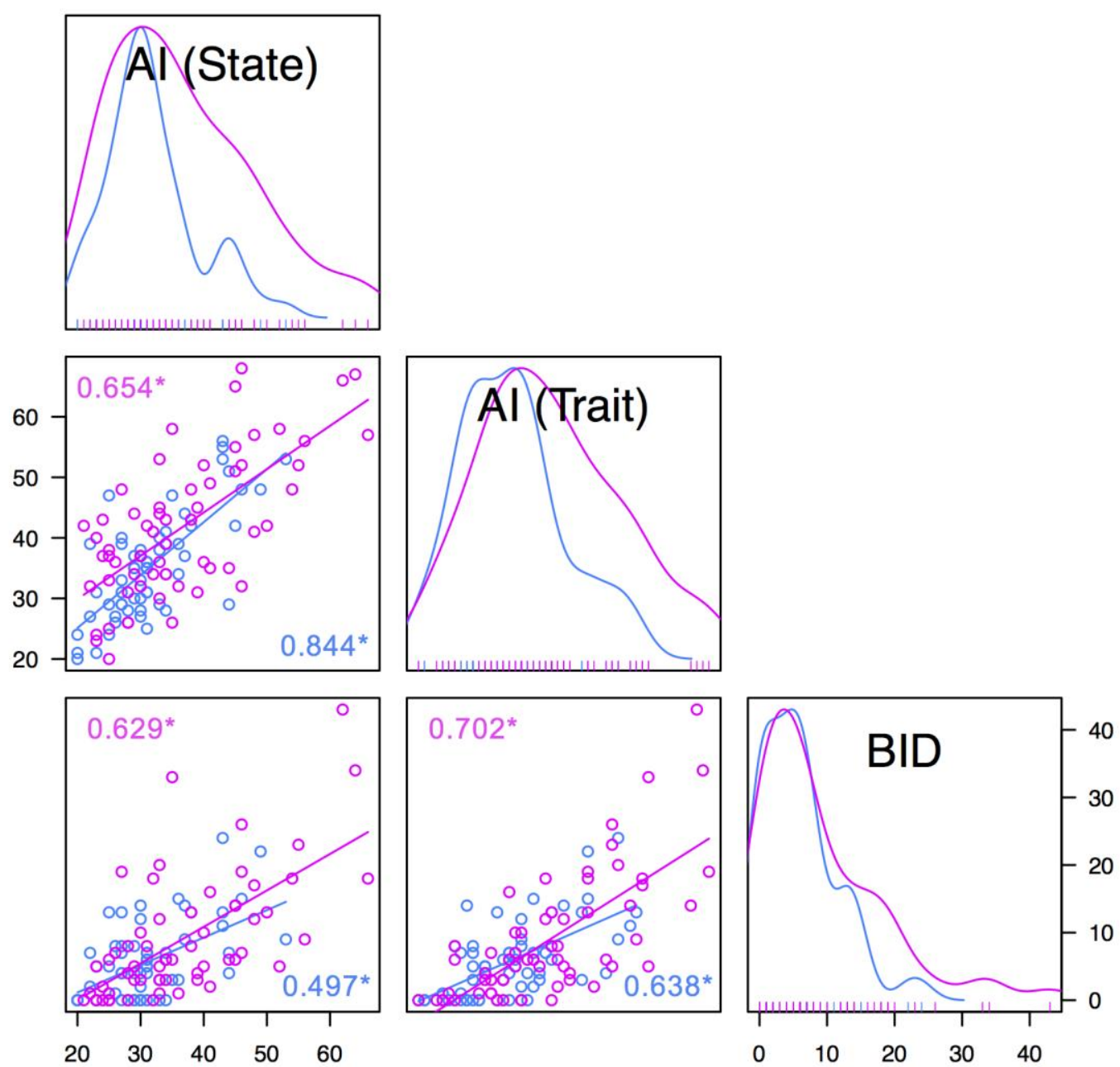


\section{References}

Abusamra, V., Abusamra, L., Sampedro, B., Difalcis, M., Dávolos, J. M., and Ferreres, A. (2014). Trastornos cognitivos en pacientes VIH-1: la dimensión pragmática de la comunicación verbal. [Cognitive disorders in HIV-1 patients: the pragmatic dimension of verbal communication.] Neuropsicologia Latinoamericana, 6(1), 22-30.

Acosta-López, JE. Mattar Khalil, SR. Riaño Garzon. ME, Rincón Lozada. CF, Díaz Camargo, EA. (2015). Aportes clínicos al deterioro cognitivo leve (DCL). Revista Fronteras del Saber. 1(7), pp. $56-63$.

Antinori, A., Arendt, G., Becker, J., Brew, B. J., Byrd, D., Cherner, M., Wojna, V. (2007). Updated research nosology for HIV-associated neurocognitive disorders. Neurology, 69, 1789 - 1799. doi:10.1212/01.WNL.0000287431.88658.8b

Amador, F., Mayor-Ríos J. and Del Castillo-Martín, N. (2006). Enlentecimiento cognitivo en sujetos seropositivos asintomáticos al virus de inmunodeficiencia humana tipo 1. [Cognitive impairment in seropositive individuals asymptomatic to human immunodeficiency virus type 1.] Revista de Neurología, (42), 129-32.

Arciniegas, Á. Malagón, T., Halliday, K., and Tovar-Cuevas, J. R. (2013). Funciones cognitivas de personas viviendo con VIH/Sida asistentes a un programa de atención integral. [Cognitive functions of people living with HIV/AIDS who are attending a comprehensive care program.] Revista Peruana de Medicina Experimental y Salud Publica, 30(3), 521-530.

Ardila-Ardila, A., Goodkin, K., Concha-Bartolini, M., Lecusay-Ruiz, R., O’Mellan-Fajardo, S., Suárez-Bustamante, P., Wilkie, F. L. (2003). HUMANS: una batería neuropsicológica para la evaluación de pacientes infectados con VIH-1. [HUMANS: a neuropsychological battery for the evaluation of HIV-1-infected patients.] Revista de Neurología, 36(8), 756-762.

Ayuso-Mateos, J. L. (1997). Trastornos neuropsiquiátricos en el SIDA. [Neuropsychiatric disorders in AIDS.] Madrid: McGraw-Hill Interamericana de España.

Beck, A., Ward, C., Mendelson, M., Mock, J., and Erbaugh, J. (1961). An inventory for measuring depression. Archives of general psychiatry, 4, 561-671.

Beckford Jarrett, S., De La Haye, W., Miller, Z. Figueroa, JP. Duncan, J. y Harvey, K. (2017). High prevalence of psychiatric and substance use disorders among persons seeking treatment for HIV and other STIs in Jamaica: a short report. AIDS Care, 3:1-5. DOI: 10.1080/09540121.2017.1384786

Benjamini, Y \& Hochberg, Y (1995) Controlling the false discovery rate: a practical and powerful approach to multiple testing. Journal of the Royal Statistical Society, Series B. 57 (1): 289300 .

Bernal-Cano, F. (2008). El virus de inmunodeficiencia humana VIH y el sistema nervioso. Principios generales. [The human immunodeficiency virus (HIV) and the nervous system. General principles.] Acta Neurológica Colombiana, 24(3), 124-141.

Bociąga-Jasik, M., Lickiewicz, B., Kalinowska-Nowak Andrzej Cieśla, A., Mach, T., and Garlicki, A. (2010). Neurocognitive disorders in HIV infected patients. HIV and AIDS Review, 9(2), 33-36.

Bornstein, R. A., Fama, R., Rosenberger, P., et al. (1993). Drug and alcohol use and neuropsychological performance in asymptomatic HIV infection. Journal of Neuropsychiatry and Clinical Neurosciences, 5(3), 254-259. 
Bragança, M., and Palha, A. (2011). Trastornos neurocognitivos asociados con la infección por el VIH. [HIV-associated neurocognitive disorders.] Actas Españolas de Psiquiatría, 39(6), 374-383.

Burgess, A. P., Riccio, M., Jadresic, D., Pugh, K., Catalan, J., Hawkins, D. A., Thompson, C. (1994). A longitudinal study of the neuropsychiatric consequences of HIV-1 infection in gay men. Neuropsychological performance and neurological status at baseline and at 12-month follow-up. Psychological medicine, 24(4), 885-889.

Castro, K. G., Ward, J. W., Slutsker, L., Buehler, J. W., Jaffe, H. W., Berkelman, R. L., y Curran, J. W. (1993). 1993 revised classification system for HIV infection and expanded surveillance case definition for AIDS among adolescents and adults. Clinical Infectious Diseases, 17(4), 802-810.

Champely, S. (2017). pwr: Basic Functions for Power Analysis. R package version 1.2-1. https://CRAN.R-project.org/package=pwr

Croucher, A. and Winston, A. (2013). Neurological complications of HIV. Medicine, 41:8.

Custodio, N., Escobar, J., and Altamirano, J. (2006). Demencia asociada a infección por virus de inmunodeficiencia humana tipo 1. [HIV-1-associated dementia.] Anales de la Facultad de Medicina, 67(3), 243-254.

Cysique L.A., Maruff P., Darby D. and Brew B.J. (2006). The assessment of cognitive function in advanced HIV-1 infection and AIDS dementia complex using a new computerised cognitive test battery. Arch Clin Neuropsychol, 21, (2), 185-94.

Elliott A. Anxiety and HIV infection (1998). STEP Perspect 98(1):11-4.

Eugenin, E. A., Osiecki, K., Lopez, L., Goldstein, H., Calderon, T. M., and Berman, J. W. (2006). CCL2/monocyte chemoattractant protein-1 mediates enhanced transmigration of human immunodeficiency virus (HIV)-infected leukocytes across the blood-brain barrier: a potential mechanism of HIV-CNS invasion and NeuroAIDS. The Journal of neuroscience, 26(4), 1098-1106.

Faílde, J. M., Lameiras, M., Rodríguez, Y., Carrera, M. V., and López, J. (2009). Características del rendimiento neuropsicológico de pacientes infectados por VIH. [Neuropsychological performance characteristics of HIV-infected patients.] Actas españolas de psiquiatría 37(5), 252-257.

Folstein, M. F., Folstein, S. E., and McHugh, P. R. (1975). "Mini-mental state": a practical method for grading the cognitive state of patients for the clinician. Journal of psychiatric research, 12(3), 189-198.

Galindo-Sainz, J., Rodríguez-Almanza, J. V., Sandoval-Ramírez, J. L., and Tejada-García, R. A. (2010). Prevalencia de alteraciones cognitivas en paciente con VIH-SIDA en una cohorte mexicana. [Prevalence of cognitive disorders in an HIV-AIDS patient in a Mexican cohort.] Medicina Interna de Mexico, 26(2), 116-122

Ghafouri, M., Amini, S., Khalili, K., and Sawaya, B. E. (2006). HIV-1 associated dementia: symptoms and causes. Retrovirology, 3(1), 28.

Golden, Ch. J. (2005). Test de colores y palabras STROOP. [STROOP color-word test.] ( $4^{\mathrm{a}}$ ed.) Madrid: Departamento I+D de TEA Ediciones S. A.

Groppe, D. M. (2016). Four things you might not (but should know) about false discovery rate control. URL: https://goo.gl/YoY9u9 Accessed November 15, 2017. 
Groppe DM, Urbach TP, Kutas M (2011) Mass univariate analysis of event-related brain potentials/fields I: a critical tutorial review. Psychophysiology 48:1711-25.

Grupo de Expertos del Grupo de Estudio de Sida (GESIDA) y Secretaría del Plan Nacional sobre el SIDA (SPNS) (2014). [Group of Experts of the Spanish AIDS Study Group (GESIDA) and Secretariat for the National Plan on AIDS (SPNS) (2014).] Documento de consenso sobre el manejo clínico de los trastornos neurocognitivos asociados a la infección por el virus de la inmunodeficiencia humana. [Consensus document on the clinical management of HIVassociated neurocognitive disorders.] Revista de enfermedades infecciosas y microbiología clínica. 32(1):37-47

Guevara-Silva (2013). Perfil cognitivo en pacientes con infección por el virus de inmunodeficiencia humana neurológicamente asintomáticos. [Cognitive profile in patients with neurologically asymptomatic human immunodeficiency virus infection.] Anales de la Facultad de Medicina, 74(1), 31-6.

Guevara-Silva, E., Custodio, N., Lira, D., Herrera-Pérez, E., Castro-Suárez, S., Nuñez del Prado, L., and Montesinos, R. (2014). Trastorno neurocognitivo asociado al virus de inmunodeficiencia humana. [HIV-associated neurocognitive disorder.] Anales de la Facultad de Medicina, 75(2), 151-157.

Habib, A., Yakasai, A., Owolabi, L., Ibrahim, A., Habibi, Z., Gudai, M., Karaye, K., Ibrahim, D. and Nashabaru (2013). Neurocognitive impairment in HIV-1 infected adults in Sub-Saharan Africa: a systematic review and meta-analysis. International Journal of Infectious Deseases 17, e820-e831. http://dx.doi.org/10.1016/j.ijid.2013.06.011

Halman, M., Chan, S., Stranks, S., Shaefer-McDanields, N. and Stewart, A. (2014). Complex care needs of patients with late-stage HIV disease: A retrospective study. AIDS Care, Vol. 26, 3, 320-355. http://dx.doi.org/10.1080/09540121.2013.819404

Heaton et al., (2010). HIV-associated neurocognitive disorders persist in the era of potent antiretroviral therapy. CHARTER Study.Neurology 75(23), 2087-2096. doi: 10.1212/WNL.0b013e318200d727

Hill, L. y Lee, Kelly (2013). Pharmacotherapy considerations in patients with HIV and psichiatric desorders: Focus on antidepressants and antipsichotic. The Annasl of Pharmacotherapic, 47: 7589.

Ian, E., et al. (2015). The burden of HIV-associated neurocognitive disorder (HAND) in the AsiaPacific region and recommendations for screening. Article in press. Asian Journal of psychiatry. http://dx.doi.org/10.1016/j.ajp.2015.10.009

Jessen F., Amariglio RE., van Boxtel M, et al. (2014) A conceptual framework for research on subjective cognitive decline in preclinical Alzheimer's disease. Alzheimer's \& Dementia: The Journal of the Alzheimer's Association, 10:844-852.

Kalinowska, S., Trześniowska-Drukała, B., and Samochowiec, J. (2013). HIV-associated neurocognitive disorders. Psychiatria Polska, 47(3), 453-463.

Kaplan, E. F., Goddglass, H. and Weintraub, S. (1983). Boston Naming Test. (2a ed.) Buenos Aires, Argentina: Editorial Médica Panamericana.

(Laverick et al., 2017). Self-reported difficulties with everyday function, cognitive symptoms and cognitive function in people with HIV. JAIDS Journal of Acquired Immune Deficiency Syndromes Publish Ahead of Print. DOI: 10.1097/QAI.0000000000001468 
Lawton, MP. and Brody, EM. (1969). Assesment of older people: self-maintaining and instrumental activities of daily living. Gerontology, 9(3), 179-86.

Lezak M., Howieson, D. and Loring, D. (1983). Neuropsychological Assesment ( $2^{a}$ ed.). Estados Unidos: Oxford University Press.

Maj, M., Starace, F., and Sartorius, N. (1991). Neuropsychiatric aspects of HIV-1 infection: data collection instrument for a WHO cross-cultural study. Bull World Health Organ, 69, 243245.

Manzanera, A. (2014). Trastornos neurocognitivos en personas con VIH +. [Neurocognitive disorders in HIV+ people] MONOGRÁFICO, 1(3), 33-42.

Marquine MJ, Heaton A, Johnson N, et al. (2017). Differences in Neurocognitive Impairment Among HIV-Infected Latinos in the United States. Journal of the International Neuropsychological Society (2017), 23, 1-13.

Martin Suarez, I., Cano Monchul, R., Pérez de Ayala, P., Aguayo Canela, M., Cuesta, F., Rodríguez, P., Pujol de la Llave, E. (2002). Calidad de vida, aspectos psicológicos y sociales en pacientes con infección VIH avanzada. [Quality of life, psychological, and social aspects in patients with advanced HIV infection.] Anales de medicina interna, 19, (8).

McAllister RH, Herns MV, Harrison MJ, et al. (1992) Neurological and neuropsychological performance in HIV seropositive men without symptoms. J Neurol Neurosurg Psychiatry 55(2):143-8

McArthur, J. C., Steiner, J., Sacktor, N. and Nath, A. (2010). Human immunodeficiency virusassociated neurocognitive disorders: Mind the gap. Annals of Neurology, (6), 699-714. doi: 10.1002/ana.22053

Mehta P, Gulevich SJ, Thal LJ, et al. (1996) Neurological Symptoms, Not Signs, Common in Early HIV Infection. J NeuroAIDS 1(2):67-85.

Millana-Cuevas, L. C., and Portellano, J. A. (2000). Evaluación Neuropsicológica de los déficit cognitivos en la infección por el virus de la inmunodeficiencia humana tipo 1 (VIH-1). [Neuropsychological assessment of cognitive deficits in human immunodeficiency virus type 1 (HIV-1) infection.] Revista de Neurología, 31(12), 1192-1201.

Ministerio de Salud y Protección Social y Fondo de población de las Naciones Unidas (2014). Guía de práctica clínica (GPC) basada en la evidencia científica para la atención de la infección por VIH/SIDA (con 13 años o más edad) y adultos. GPC-2014-39. Bogotá, Colombia.

ONUSIDA (2015a). Estimaciones sobre el VIH y el SIDA. [Estimates of HIV and AIDS.] Retrieved from: http://www.unaids.org/es/regionscountries/countries/colombia

ONUSIDA (2015b). Estadísticas globales. [Global statistics.] Retrieved from: Hoja informativa 2015. [Fact sheet 2015] http://www.unaids.org/sites/default/files/media_asset/20150901_FactSheet_2015_es.pdf

Otrosky-Solis, F., Ardila, A. and Rosselli, M. (1999). Evaluación Neuropsicológica breve en español (Neuropsi). [Brief Neuropsychological Assessment in Spanish (Neuropsi).] Mexico: Publingenio, S.A.

Parry, S., Zetler, S., Kentridge, A., Petrak, J. and Barber, T. (2017). Simple screening for neurocognitive impairment in routine HIV outpatient care: is it deliverable? AIDS Care, 14: 1-5 doi: 10.1080/09540121.2017.1300632. 
Paul, R., Cohen, R., Navia, B. and Tashima, K. (2002). Relationship between cognition and structural neuroimaging findings in adults with human immunodeficiency virus type- 1 . Neuroscience and Biobehavioral Reviews, (26), 353-359.

Perdices M, Dunbar N, Grunseit A, et al. (1992) HIV related symptomatology across the spectrum of HIV disease. Aust N Z J Psychiatry 26(4):560-6.

Pino-Melgarejo, M. and Omar-Martínez, E. (2014). Cognición y VIH. Algunas consideraciones. [Cognition and HIV. Some thoughts.] Santiago (135), 664-674.

Portellanos, J. (2005). Introducción a la Neuropsicología. [Introduction to Neuropsychology.] España: McGraw-Hill.

Pumpradit W, Ananworanich J, Lolak S, et al. (2010) Neurocognitive impairment and psychiatric comorbidity in well-controlled human immunodeficiency virus-infected Thais from the $2 \mathrm{NN}$ Cohort Study. J Neurovirol 16(1):76-82.

Rackstraw, S. (2011). HIV-related neurocognitive impairment-A review. Psychology, Health and Medicine, 16(5), 548-563.

Rey, A. (1964). L'examen clinique en psychologie. Paris: Presses Universitaires de France.

Rey, A. (2003). Test de copia y de reproducción de memoria de figuras geométricas complejas. [Rey-Osterrieth Complex Figure Test.] ( $8^{\mathrm{a}}$ ed.). Madrid: TEA Ediciones. [TEA Publishers].

Robertson, K., Bayon, C., Molina, J., et al. (2014). Screening for neurocognitive impairment, depression, and anxiety in HIV-infected patients in Western Europe and Canada. AIDS Care, Vol. 26, No. 12, 1555-1561. http://dx.doi.org/10.1080/09540121.2014.936813

Salawu, F. K., Bwala, S. A., Wakil, M. A., Bani, B., Bukbuk, D. N., and Kida, I. (2008). Cognitive function in HIV-seropositive Nigerians without AIDS. Journal of the neurological sciences, 267(1), 142-146.

Sánchez-Fernández, M., y Tomateo-Torvisco, D. (2014). Síndromes psiquiátricos en personas infectadas con el Virus de la Inmunodeficiencia Humana: una revisión breve. Revista de NeuroPsiquiatría, 77(2), 70-77.

Selnes, O. A., and Miller, E. N. (1994). Development of a screening battery for HIV-related cognitive impairment: The MACS experience. In I. Grant and A. Martin (Eds.), Neuropsychology of HIV infection (pp. 176). USA: Oxford University Press.

Schmidt, M. (1996). Rey Auditory and Verval Learning Test: A handbook. Los Angeles, CA: Western Psychological Services.

Sherr, L., Cluclas, C., Harding, R., Sibley, E. and Catalan, J. (2011). HIV and Depression - a systematic review of interventions. Psychology, Health \& Medicine, (16) 5, 493-527.

Spielberger, C. D. and Díaz-Guerrero (1975). IDARE. Inventario de Ansiedad: Rasgo-Estado. Manual e Instructivo. [Trait-State Anxiety Inventory. Manual and Instruction.] Mexico: Manual Moderno. [Modern Manual.]

Spreen, O. and Strauss, E. (1998). A compendium of neuropsychological tests. (2 $\left.{ }^{\mathrm{a}} \mathrm{ed}.\right)$ New York: Oxford University.

Storey, J. D., \& Tibshirani, R. (2003). Statistical significance for genomewide studies. Proc Natl Acad Sci U S A, 100(16), 9440-9445.

Towgood, K. J., Pitkanen, M., Kulasegaram, R., Fradera, A., Kumar, A., Soni, S., . . Kopelman, M. D. (2012). Mapping the brain in younger and older asymptomatic HIV-1 men: Frontal volume changes in the absence of other cortical or diffusion tensor abnormalities. Cortex, 48(2), 230241. 
Vance, D., Randazza, J., Fogger, S., Slater, L., Humphrey, S., and Keltener, N. (2014). An overview of the biological and psychosocial context surrounding neurocognition in HIV. Journal of the American Psychiatric, Nurses Association, 20(2), 117-124. Doi: $10.1177 / 1078390314527549$.

Vera-Villaroel, P., Pérez, V., Moreno, E., and Allen de F. (2004). Diferencias en variables psicosociales en sujetos VIH homosexuales y heterosexuales. [Differences in psychosocial variables in homosexual and heterosexual HIV subjects.] Internacional Journal of Clinical and Health Psychology, 4, 55-67.

Vally, Z. (2011). HIV-associated neurocognitive disorders. South African Journal of Psychiatry, 17(4), 98-102.

Venier, A., Murillo, P., Godoy, J. (2012). Evaluación de las Funciones Ejecutivas en Personas con VIH Asintomático. [Assessment of Executive Functions in People with Asymptomatic HIV.] Revista Neuropsicología, Neuropsiquiatría y Neurociencias, 12, (2), 129-141 129 ISSN: 0124-126

Vélez JI, Correa JC, Arcos-Burgos M (2014) A new method for detecting significant $p$-values with applications to genetic data. Revista Colombiana de Estadistica 37:67-76.

Vélez, J.I., Lopera,F., Sepulveda-Falla, D., et al. (2016). APOE*E2 allele delays age of onset in PSEN1 E280A Alzheimer's disease. Mol Psychiatry. 21(7):916-24. doi: 10.1038/mp.2015.177.

Vergara E., García A., García M. and Vergara A. (2010). Alteraciones neurocognitivas asociadas al virus de la inmunodeficiencia humana en pacientes marginales con trastornos por consumo de sustancias. [HIV-associated neurocognitive disorders in marginal patients with substance use disorders.] Revista Alzheimer, (46), 37-43.

Villaseñor-Cabrera, T., and Rizo-Curiel, G. (2003). Trastornos cognoscitivos asociados al efecto del VIH/sida en el cerebro. Estudio comparativo entre los estadios inicial y final. [Cognitive disorders associated with the effect of HIV/AIDS on the brain. Comparative study between the initial and final stages.] Investigación en Salud, 5(3), 146-153.

Weber E, Blackstone K, Woods SP (2013). Cognitive neurorehabilitation of HIV-associated neurocognitive disorders: a qualitative review and call to action. Neuropsychol Rev. 23(1):81-98. doi: 10.1007/s11065-013-9225-6.

Wechsler, D. (2001). Manual de aplicación y corrección de la escala de inteligencia de Wechsler (WAIS-III). [Wechsler Intelligence Scale Application and Correction Manual (WAIS-III).] Madrid: TEA Ediciones. [TEA Publishers].

Wechsler, D. (2004). Escala de memoria de Wechsler-III. [Wechsler memory scale-III.] Madrid: TEA Ediciones.

White, D. A., Heaton, R. K., Monsch, A. U. and The HNRC Group (1995). Neuropsychological studies of asymptomatic human immunodeficiency virus type-1 infected individuals. Journal of the International Neuropsychological Society, (1), 304-315.

Wilkie, F. L., Eisdorder, C., Morgan, R. Loewenstein, D. A. and Szapocznick, J. (1990). Cognition in early human immunodeficiency virus infection. Archives of Neurology, (47), 433-440.

Woods, S. P., Moore, D. J., Weber, E., and Grant, I. (2009). Cognitive neuropsychology of HIVassociated neurocognitive disorders. Neuropsychology review, 19(2), 152-168. 